\title{
PENGEMBANGAN MEDIA BUS RACE ALGEBRA PADA MATERI BENTUK ALJABAR UNTUK SISWA KELAS VII SMP
}

\author{
Eko Yulianto Prambudi ${ }^{1}$, Tri Nova Hasti Yunianta ${ }^{2}$ \\ ${ }^{1,2}$ Universitas Kristen Satya Wacana, Jalan Diponegoro 52-60 Salatiga, Indonesia \\ 202016003@student.uksw.edu
}

\begin{abstract}
There are students still having difficulty in learning mathematics specifically on algebraic form material. This is because the teacher still uses the lecture method and relies on Student Worksheet as a learning reference that students consider less effective and enjoyable, so we need a fun learning media so that students also enjoy in learning mathematics. This study aims to produce a board games learning media in the form of Algebra Bus Race which used for VII grade students of junior high school on the subject of algebraic form. This type of research is research and development using the ADDIE model. The research subjects were 15 students from grade VII students of SMP N 2 Doplang, SMP N 5 Salatiga, Mts PSM Randublatung. Data collection techniques in the form of observation, tests, and documentation with data analysis techniques in the form of validity analysis, effectiveness analysis, practicality analysis. The results of this development study the average percentage of validity values in terms of material is $88.34 \%$ with a very good category. And the average percentage of validity values in terms of media is $83.33 \%$ with a very good category. The average percentage of practicality is $88.35 \%$ with a very good category. The results of the value of the paired t-test were less than 0.05 with an average pretest value of 56.00 increasing to 84.50 at post-test. Student opinion sheets get a very positive response to the learning media of Bus Race Algebra with an average percentage of students' opinions of the Bus Race Algebra media is $90.00 \%$ with a very good category.
\end{abstract}

Keywords : Media Development, Bus Race Algebra, Algebraic Form

\begin{abstract}
Abstrak
Terdapat siswa masih kesulitan dalam belajar matematika kususnya pada materi bentuk aljabar. Hal ini disebabkan karena guru masih menggunakan metode ceramah dan mengandalkan LKS sebagai acuan belajar yang dianggap siswa kurang efektif dan menyenangkan, sehingga diperlukan media belajar yang menyenangkan agar siswa juga senang belajar matematika. Penelitian ini bertujuan menghasilkan suatu media pembelajaran board games berupa Bus Race Algebra yang digunakan untuk siswa kelas VII Sekolah Menengah Pertama pada pokok bahasan bentuk aljabar. Jenis penelitian ini adalah penelitian dan pengembangan dengan menggunakan model ADDIE. Subjek Penelitian adalah sebanyak 15 siswa dari siswa kelas VII SMP N 2 Doplang, SMP N 5 Salatiga, Mts PSM Randublatung. Teknik pengumpulan data berupa observasi, tes, dan dokumentai dengan teknik analisis data berupa analisis kevalidan, analisis keefektifan, analisis kepraktisan. Hasil penelitian pengembangan ini persentase rata-rata nilai kevalidan dari segi materi adalah $88,34 \%$ dengan kategori sangat baik dan Persentase rata-rata nilai kevalidan dari segi media adalah 83,33\% dengan kategori sangat baik. Persentase rata-rata nilai kepraktisan adalah $88,35 \%$ dengan kategori sangat baik. Hasil nilai dari uji pair $t$-test adalah kurang dari 0,05 dengan rata rata nilai pretest 56,00 meningkat menjadi 84,50 pada nilai postest. Lembar pendapat siswa mendapatkan respons yang sangat positif terhadap media pembelajaran Bus Race Algebra dengan rata-rata persentase pendapat siswa terhadap media Bus Race Algebra adalah 90,00\% dengan kategori sangat baik.
\end{abstract}

Kata Kunci : Pengembangan Media, Bus Race Algebra, Bentuk Aljabar

\section{PENDAHULUAN}

Matematika merupakan mata pelajaran yang dikenalkan sejak dari PAUD sampai di perguruan tinggi. Cara seorang guru mengajarkan matematika beraneka ragam tergantung karakteristik seorang guru maupun pendidik. Hal tersebut sejalan dengan Arsyad (2011) yang menyatakan bahwa materi lebih mudah dipahami siswa tergantung cara penyampaian dan penyajiannya. Listiani \& Prihatnani (2018) mengungkapkan bahwa faktor yang menimbulkan siswa bosan belajar dikarenakan pemberian latihan soal-soal yang disajikan dalam kegiatan kurang menarik. Memberikan latihan soal yang monoton secara terus menerus akan membosankan dan tidak menarik 
(Kharimah dkk, 2014). Diperlukan suatu kegiatan yang menarik dalam menyajikan latihan soal dan materi, salah satunya adalah penggunaan media pembelajaran.

Perlu adanya strategi penyajian materi dan latihan soal yang ampuh dan siswa dapat berperan aktif dalam kegiatan pembelajaran (Putri \& Yunianta, 2018). Menghadirkan media berbasis permainan merupakan salah satu strategi untuk mewujudkan hal tersebut. Harsono \& Prihatnani (2018) mengungkapkan bahwa memadukan unsur permainan kedalam media mampu meningkatkan motivasi siswa untuk lebih aktif dan tidak mudah jenuh dan bosan.

Penggunaan media juga dibutuhkan dalam menyampaikan materi bentuk aljabar. Siswa menganggap materi tersebut susah karena siswa kebanyakan sulit mengubah soal cerita ke dalam bentuk matematika dan kesusahan mengoperasikan bentuk aljabar seperti penjumlahan, pengurangan, perkalian dan pembagian (Warsitasari, 2015). Hal tersebut dikarenakan belum adanya media yang ampuh untuk menyampaikan maupun menyajikan materi, sehingga pembelajaran kurang efektif yang berdampak pada prestasi belajar siswa kurang memuaskan. Permasalahan yang terjadi dikarenakan keterbatasan alat atau media yang memadai dalam penyampaian materi sehingga proses pembelajaran belum maksimal.

Beberapa penelitian yang telah mengembangkan media pembelajaran, diantaranya yaitu penelitian yang dilakukan oleh Malalina (2017) yaitu mengembangkan media ular tangga untuk meningkatkan motivasi belajar pada materi keliling dan luas segitiga. Siswa yang awalnya bosan, mengantuk dan lelah, pada akhirnya dengan belajar menggunakan media tersebut suasana siswa menjadi lebih ceria dan lebih semangat untuk belajar. Penelitian serupa juga dilakukan oleh Mujito (2018) yaitu memecahkan masalah matematika pada materi luas dan keliling bangun datar dengan mengembangkan media ular tangga berbasis android. Pemecahan masalah matematika siswa sangat baik yaitu rata-rata hasil evaluasi mencapai 88,84 setelah menggunakan media tersebut. Afandi (2015) mengembangkan media yang bertujuan untuk meningkatkan hasil belajar siswa yang memfokuskan penyederhanaan konsep matematika, karena kebanyakan siswa mengeluh dan takut akan matematika hal tersebut akan menjadikan minat belajar menurun. Berdasarkan hasil penelitian-penelitian dan permasalahan di atas maka munculah ide untuk mengembangkan media pembelajaran bernama "Bus Race Algebra" yang menarik minat belajar siswa dan efektif digunakan dalam proses pembelajaran serta dapat membantu pemecahan masalah matematika siswa.

Kelebihan dari media "Bus Race Algebra" bukan hanya sekedar bermain saja akan tetapi media ini dikemas dengan baik yaitu dilengkapi dengan soal-soal pertanyaan tentang pemecahan masalah bentuk aljabar, diharapkan dengan media "Bus Race" ini dapat meningkatkan minat belajar siswa karena balajar sambil bermain itu menyenangkan. Menurut Azis (2018), suatu alat atau media belajar berupa permainan edukatif yang digunakan untuk kegiatan belajar sambil bermain. Hal tersebut sejalan dengan penelitian Setyaningsih \& Dewi (2018) yang menyatakan bahwa pembelajaran yang menyenangkan adalah ketika pembelajaran dilakukan dengan cara sambil bermain, dikarenakan siswa tidak akan merasa tertekan dan bosan untuk belajar. Muatan kognitif semakin 
mudah diserap oleh siswa, penggunaan media secara tidak langsung membuat siswa menyukai materi yang diajarkan dengan cara belajar sambil bermain

Berdasarkan hal di atas maka perlu adanya pengembangkan media yang sesuai dengan kebutuhan proses pembelajaran sebagai sarana latihan soal-soal khususnya pada materi bentuk aljabar. Media ini diharapkan mampu memotivasi siswa untuk lebih giat belajar sehingga prestasi belajar siswa dapat meningkat. Penelitian pengembangan ini dilakukan guna memperoleh suatu media pembelajaran yang efektif, valid, serta praktis untuk menyajikan materi serta sebagai sarana latihan soal dalam matematika. Dengan adanya media "Bus Race" diharapkan dapat membantu guru dalam menyajikan materi dan latian soal yang inovatif dan ampuh menarik minat belajar siswa.

\section{Media pembelajaran}

Indriana (2011: 3) menyatakan bahwa bentuk jamak yang berasal dari bahasa latin yang berarti bentuk jamak dari kata medium sebagai alat hubungan komunikasi. Secara harfiah, media mempunyai makna "perantara" atau "tengah", sehingga dapat dikatakan perantara antara penerima pesan dan sumber pesan. Harsantik (2014) mengemukakan bahwa pembelajaran merupakan proses pada setiap orang untuk lebih baik yang terjadi secara alamiah dari yang awalnya tidak tahu dan akhirnya menjadi tahu. Berdasarkan uraian tersebut dapat disimpulkan bahwa media pembelajaran adalah segala benda ataupun alat penghubung guna mempermudah proses pembelajaran dan penyampaian informasi yang dilakukan oleh guru terhadap siswa agar informasi tersebut dapat ditangkap dengan mudah.

\section{Board Games}

Jenis permainan nondigital atau konvensional yang mempunyai berbagai keunggulan dibandingkan dengan jenis permainan lainnya (Latief, 2017). Board Games biasanya sering disebut dengan permainan papan dimana orang orang bermain menggunakan papan permainan yang seru dan menyenangkan. Tujuan utama dari Board Games bukan hanya bermain dan persaingan saja, akan tetapi mencairkan keaktifan komunikasi antar pemain dan juga mengakrabkan hubungan antar pemain.

\section{Fungsi Media}

Seperti halnya yang dikemukakan diatas bahwa media pembelajaran diartikan sebagai alat yang menjembatani dalam penyampaian informasi atau pesan. Media juga mempunyai fungsi yang salah satunya yang paling menoonjol adalah menyalurkan informasi. Kemp dan Dayton (Pribadi, 2009) mendefinisikan fungsi media sebagai berikut: 1) memotivasi minat atau tindakan agar dapat menjalankan fungsi dari motivasi itu sendiri, maka hiburan atau teknik drama dapat digunakan dalam merealisasikan media pembelajaaran; 2) menyajikan informasi yang meliputi isi dan bentuk media yang disampaikan kepada beberapa kelompok orang merupakan salah satu hal yang digunakan dalam penggunaan media pembelajaran; 3) memberi instruksi dimana informasi yang terdapat di dalam media tersebut harus mengaitkan siswa antara logika dan psikologis dalam bentuk kegiatan yang menarik sehingga pembelajaran menjadi efektif. 
PEngembangan Media Bus Race Algebra Pada Materi Bentuk Aljabar Untuk Siswa Kelas VII SMP, Eko Yulianto Prambudi, Tri Nova Hasti Yunianta

\section{Pemilihan Media yang Baik}

Terdapat banyak faktor yang digunakan untuk memilih media, pada dasarnya saat mengambil keputusan memilih media perlu mempertimbangkan tujuan dan media tersebut serta terpenuhinya kebutuhan dilapangan. Media dikatakan tidak dapat digunakan ketika tidak sesuai dengan tujuan dan kebutuhan pembelajaran (Indrawati Dkk, 2014). Beberapa prinsip-prinsip yang digunakan dalam memilih tepat tidaknya media pengajaran maupun pembelajaran menurut Indriana (2011: 28) adalah sebagai berikut: (a) ketepatan dalam tujuan pembelajaran; (b) ketepatan materi yang disampaikan; (c) ketepatan ditinjau dari faktor eksternal (fasilitas pendukung, waktu, serta kondisi lingkungan; (d) ketepatan dengan karakteristik siswa.

\section{METODE}

Jenis penelitian ini adalah penelitian dan pengembangan (Research and Development) dengan menggunakan model ADDIE. Populasi pada penelitian ini adalah siswa kelas VII Sekolah Menengah Pertama, sedangkan sampel pada penelitian ini terdapat 3 Sekolah yaitu: SMP Negeri 2 Doplang, SMP Negeri 5 Salatiga, Mts PSM Randublatung. Sebanyak 15 siswa dipilih dari ketiga SMP tersebut dijadikan sebagai subjek penelitian. Teknik pengumpulan data berupa observasi, tes, dan dokumentasi dengan teknik analisis data berupa analisis kevalidan, analisis keefektifan dan analisis kepraktisan (Sugiyono, 2012). Penelitian ini dilaksanakan pada bulan Januari sampai bulan Agustus 2019.

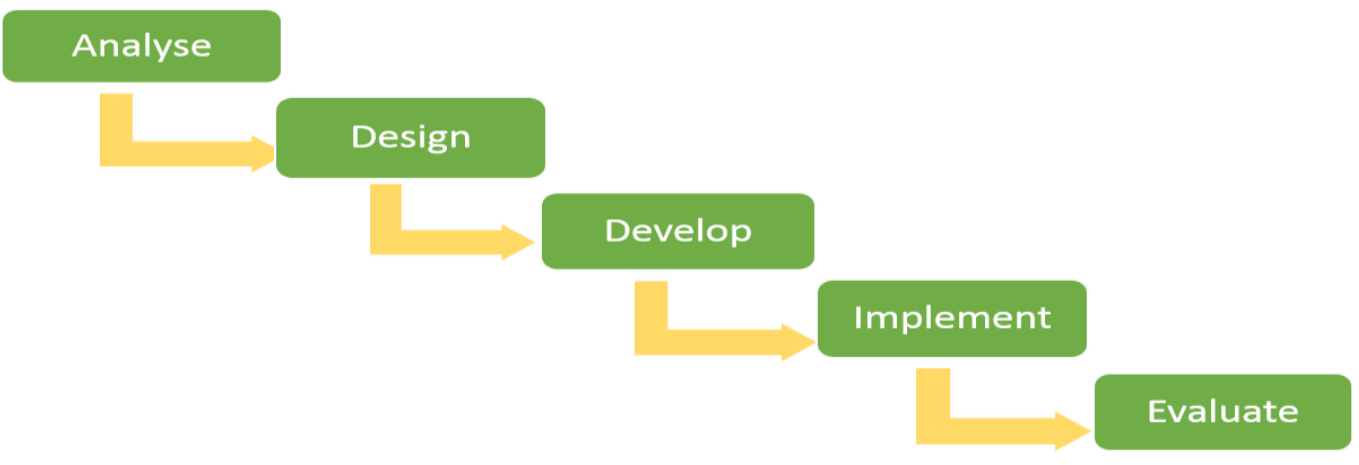

Gambar 1. Diagram Model ADDIE

\section{HASIL}

Model pengembangan ADDIE digunakan dalam penelitian pengembangan ini dengan menggunakan 5 tahapan yaitu: 1) Analyze; 2) Desain; 3) Development; 4) Imlementasion; 5) Evaluasi (Sadiman Dkk, 2010).

\section{Analize (Analisis)}

Berdasarkan hasil wawancara yang dilakukan disekolah didapatkan hasil terdapat siswa yang kesulitan mengerjakan soal-soal pada materi bentuk aljabar. Temuan lain, siswa merasa bosan terhadap kegiatan belajar mengajar dikelas yang monoton dikarenakan guru memberikan banyak 
latian soal kepada siswa sehingga kegiatan belajar kurang menarik minat untuk belajar. Metode yang kurang sesuai dengan karakteristik siswa yang digunakan oleh guru pada saat kegiatan belajar mengajar. Siswa merasa jenuh dan bosan dikarenakan pembelajaran yang monoton dan pemberian soal secara terus menerus. Siswa membutuhkan suatu media pembelajaran yang dikemas dalam bentuk permainan yang dapat melatih siswa yang dijadikan sebagai latihan soal. Terdapat banyak media pembelajaran yang bertujuan sebagai sarana latihan soal, salah satunya adalah dengan Bus Race Algebra.

\section{Design (Desain)}

\section{Aturan Permainan}

Media Bus Race Algebra dimainkan secara berkelompok dengan tujuan berlatih soal pada materi bentuk aljabar. Terdapat peraturan permainan supaya media ini dapat dimainkan secara efektif sebagai berikut: (a) menentukan salah satu orang untuk menjadi wasit atau juri dan memegang kunci jawaban untuk menentukan benar salahnya jawaban; (b) dimulai dengan cara melakukan hompimpa guna menentukan siapa yang memulai terlebih dahulu; (c) setelah menentukan pemain pertama kali, dilanjutkan dengan mengambil kartu permainan; (d) jika dan mendapatkan kartu yang isi didalamnya terdaat pertanyaan maka pemain wajib untuk menjawabnya; (e) jika pemain tidak bisa menjawab maka bidak tetap dipetak tersebut; (f) apabila berhasil menjawab soal maka bidak melangkah sesuai jumlah rambu lalu lintas; (g) kartu bergambarkan bengkel maka bidak melangkah maju sesuai jumlah jumlah rambu lalu lintas; (h) kartu bergambarkan ban maka bidak melangkah mundur sesuai jumlah rambu lalu lintas; (i) satu petak hanya bisa ditempati 1 bidak; (j) jika terdapat 1 bidak lebih dalam satu petak, maka bidak pertama yang menempati petak tersebut harus mundur 2 langkah; (k) pemain dianggap sebagai pemenang ketika sudah sampai pada angka 65 atau petak terakhir.

\section{Desain Logo Bus Race Algebra}

Pada desain logo media ini memadukan antara gambar bus dan papan rambu lalulintas. Adapun logo untuk Bus Race Algebra yang didesain menggunakan aplikasi Adobe Photoshop dan Corel Draw dapat dilihat pada Gambar 4.1.

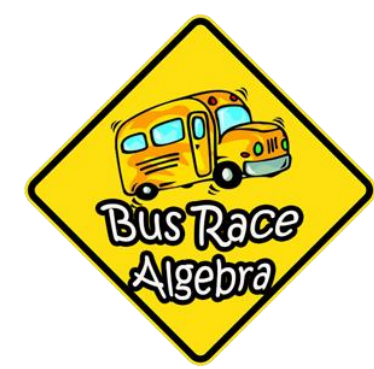

Gambar 2. Logo Media Bus Race Algebra

\section{Desain Peta Permainan}

Desain papan media ini dibuat dengan aplikasi Corel Draw dengan mengangkat tema rute perjalanan bus. Terdapat petak-petak disepanjang rute dan terdapat nomor nomor sebagai urutan 
PEngembangan Media Bus Race Algebra Pada Materi Bentuk Aljabar Untuk Siswa Kelas VII SMP, Eko Yulianto Prambudi, Tri Nova Hasti Yunianta

perjalanan permainan. Dimulai dari angka 1 dan finish atau selesai di angka 65. Desain papan media dapat dilihat pada Gambar 4.2.

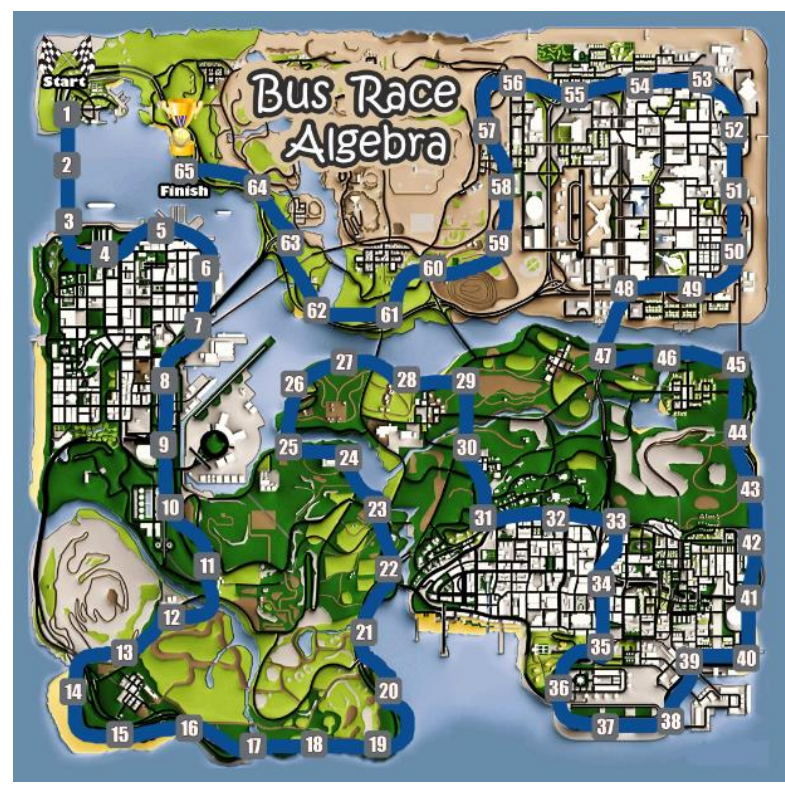

Gambar 3. Desain Peta Permainan

Desain Buku Petunjuk dan Kunci Jawaban

Pada halaman depan buku panduan terdapat judul "Buku Petunjuk dan Kunci Jawaban", serta terdapat logo dari Bus Race Algebra dan juga Kompetensi Dasar pada materi bentuk aljabar. Pada halaman belakang buku panduan terdapat peraturan bermain Bus Race. Buku petunjuk tersebut didesain menggunakan aplikasi Adobe Photoshop dapat dilihat pada Gambar 4.3.

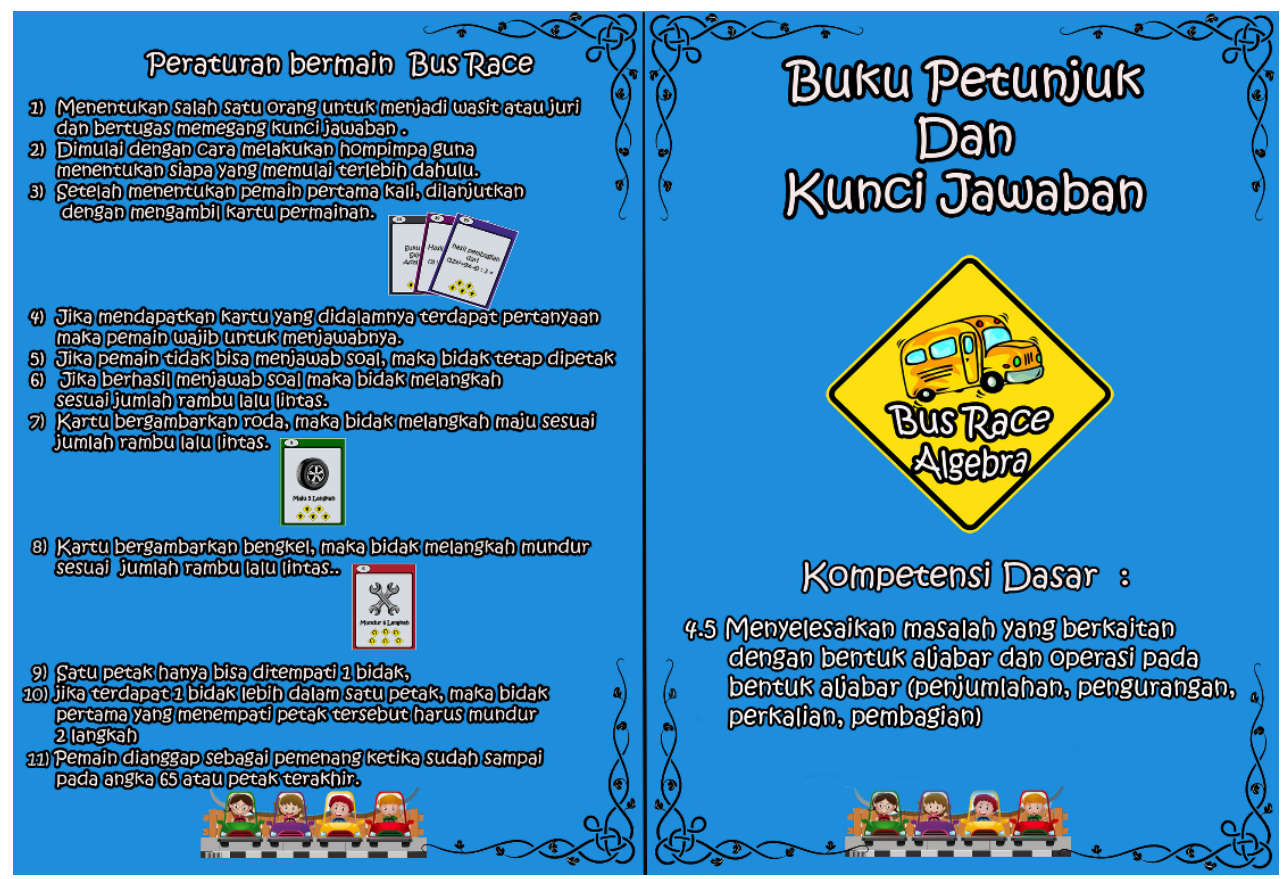

Gambar 4. Buku Petunjuk Halaman Depan Dan Belakang

Selanjutnya pada bagian dalamnya terdapat buku petunjuk mengenai komponen dari media Bus Race Algebra dan juga kunci jawaban kartu permainan. Pada halaman komponen media Bus 
Race terdapat 4 komponen yaitu: 1)papan permainan; 2) kartu permainan; 3)buku petunjuk dan kunci jawaban; 4)bidak. Kunci jawaban kartu permainan terletak setelah halaman komponen media dengan perincian: 1)maju 2 langkah kunci jawaban nomor 11-22; 2)maju 3 langkah kunci jawaban nomor 2334; 3)maju 4 langkah kunci jawaban nomor 35-46; 4)maju 5 langkah kunci jawaban nomor 47-58; 5)maju 6 langkah kunci jawaban nomor 59-70; 6)maju 1 langkah kunci jawaban nomor 71-84. Adapun gambar buku petunjuk dan kunci jawaban Bus Race Algebra yang didesain menggunakan aplikasi Adobe Photoshop dan Corel Draw dapat dilihat pada Gambar 4-6.

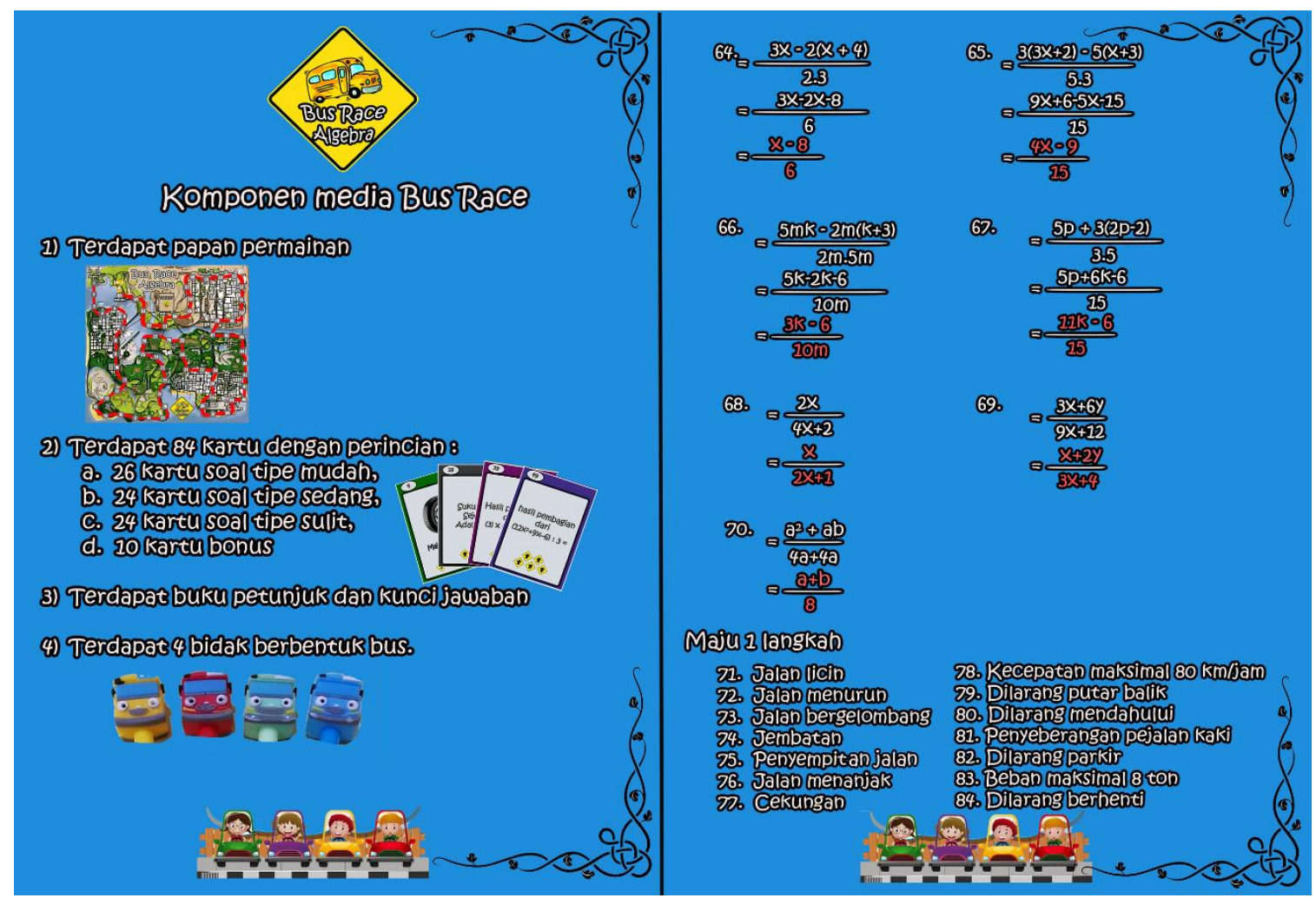

Gambar 5. Komponen Media dan Kunci Jawaban

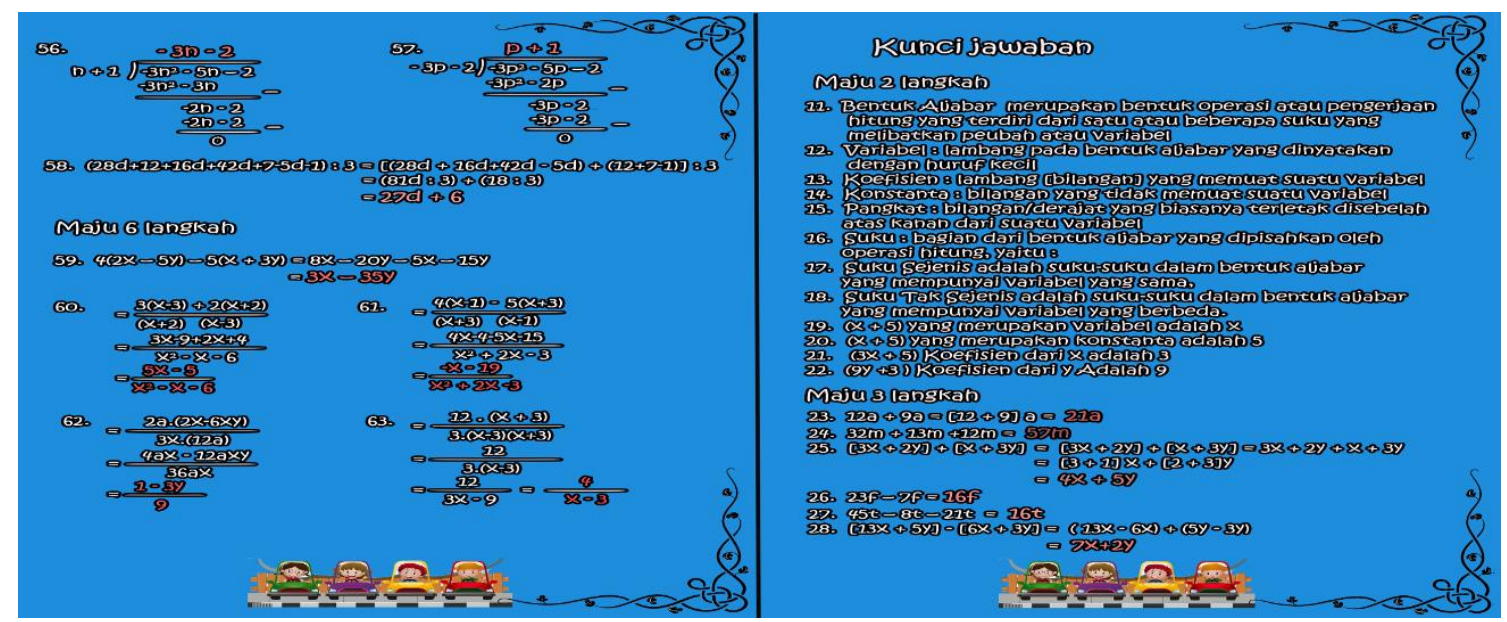

Gambar 6. Kunci Jawaban 


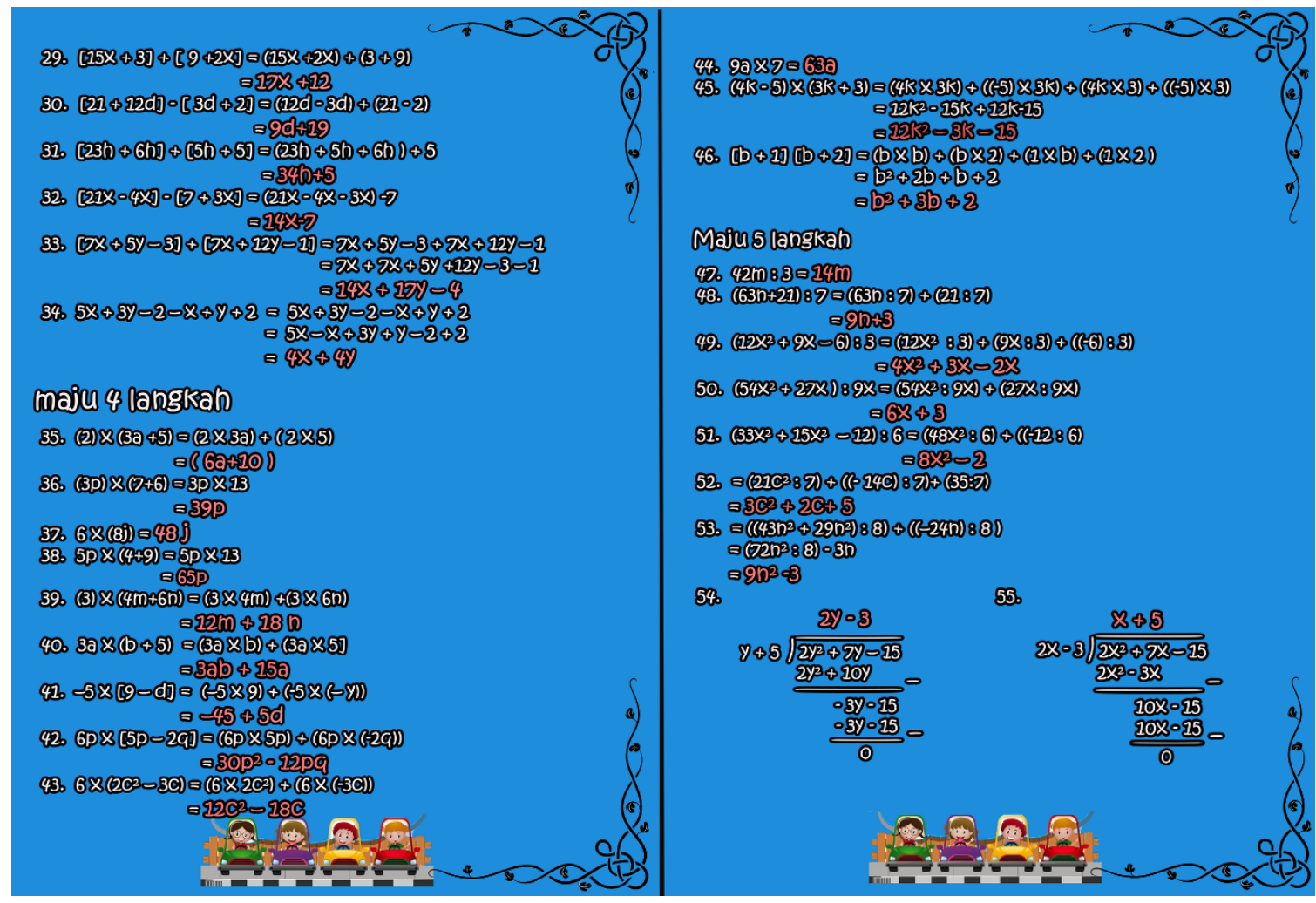

Gambar 7. Kunci Jawaban

\section{Desain Kartu Permainan}

Tahap selanjutnya yaitu mendesain kartu permainan, Desain kartu permainan terbagi menjadi 2 yaitu desain bagian luar dan desain bagian dalam. Desian bagian luar berwarna hitam ke abu-abuan dan terdapat logo Bus Race Algebra. Adapun desain kartu permainan bagian luar yang dibuat dengan menggunakan aplikasi Adobe Photoshop dan Corel Draw dapat dilihat pada Gambar 4.7.

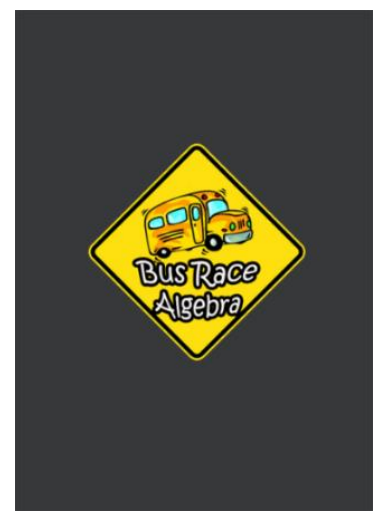

Gambar 8. Kartu Permainan Bagian Luar

Pada desain kartu permainan bagian dalamnya terdapat berbagai pertanyaan-pertanyaan yang sesuai dengan tingkat kesulitan soal. Pada bagian pojok kiri atas kartu permainan terdapat nomor soal yang digunakan untuk mencocokkan jawaban dengan kunci jawaban. Ditengah kartu permainan terdapat pertanyaan-pertanyaan mengenai materi bentuk aljabar, serta pada bagian bawah kartu permainan terdapat langkah permainannya yang bergambar rambu lalu lintas. Adapun gambar kartu permainan yang dibuat menggunakan Adobe Photoshop dapat dilihat pada Gambar 8. 


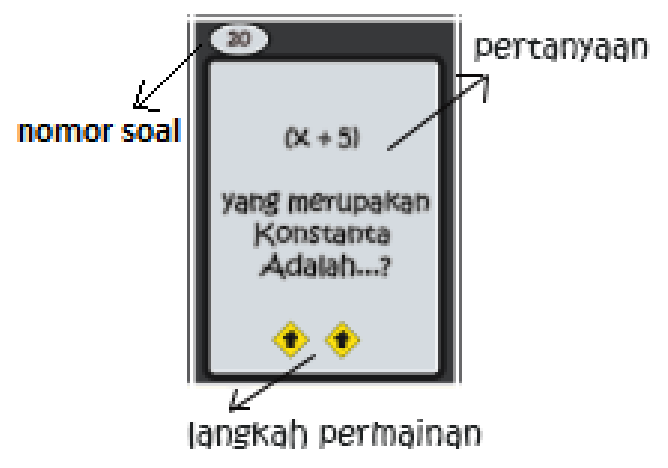

Gambar 9. Kartu Pertanyaan Bagian Dalam

Terdapat 84 kartu permainan yang didesian dengan perincian: 10 kartu bonus, 26 kartu permainan tipe mudah, 24 kartu permainan tipe sedang, dan 24 kartu permainan dengan tipe sulit.

\section{Kemasan Kartu Permainan}

Setelah desain kartu permainan selesai, tahap selanjutnya adalah mendesain kemasan kartu sebagai tempat kartu permainan. Desain kemasan pada bagian depan terdapat logo Bus Race Algebra dan dibawahnya terdapat tulisan "Kartu Permainan" disertai beberapa gambar kartu permainan dengan latar belakang warna hitam keabu-abuan. Pada bagian samping kakan dan kiri kemasan terdapat tulisan "Bus Race Algebra" dengan latar belakang berwarna abu-abu.. Adapun desain kemasan kartu permainan yang dibuat menggunakan Correl Draw dapat dilihat pada Gambar 4.9.

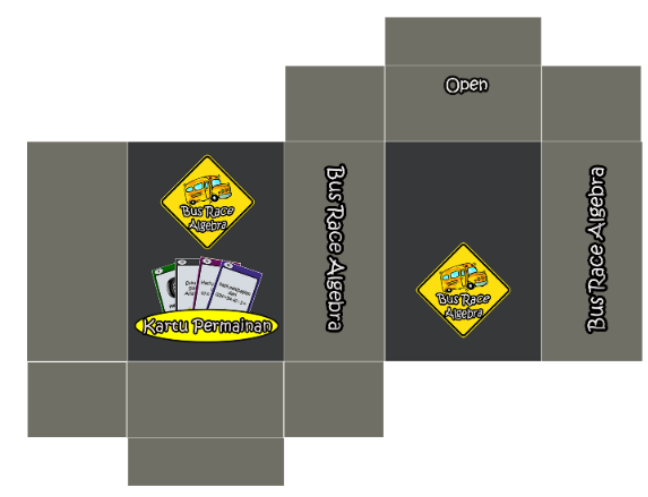

Gambar 10. Kemasan Kartu Permainan

\section{Bidak Permainan}

Bidak permainan dibuat dengan bahan karet berbentuk bus. Bahan karet digunakan karena tidak mudah rusah dan tidak licin pada ssat digunakan dipapan permainan. Terdapat 4 bidak permainan dengan warna yang berbeda-beda yaitu: biru, hijau, merah, dan toska. Bidak permainan dapat dilihat pada Gambar 10.

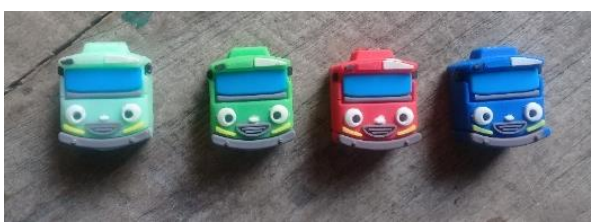

Gambar 11. Bidak Permainan 
PEngembangan Media Bus Race Algebra Pada Materi Bentuk Aljabar Untuk Siswa Kelas VII SMP, Eko Yulianto Prambudi, Tri Nova Hasti Yunianta

\section{Papan Permainan}

Papan permainan ini dibuat menggunakan bahan plastik karena sifatnya yang ringan dan awet digunakan. Papan terbagi menjadi 2 bagian yaitu bagian luar sebagai papan permainan Bus Race Algebra dan bagian dalam sebagai tempat menyimpan semua komponen permainan. Pada bagian luarnya akan ditempel stiker bergambarkan peta permainan yang sudah didesain. Papan bagian luar dapat dilihat pada Gambar 4.11.

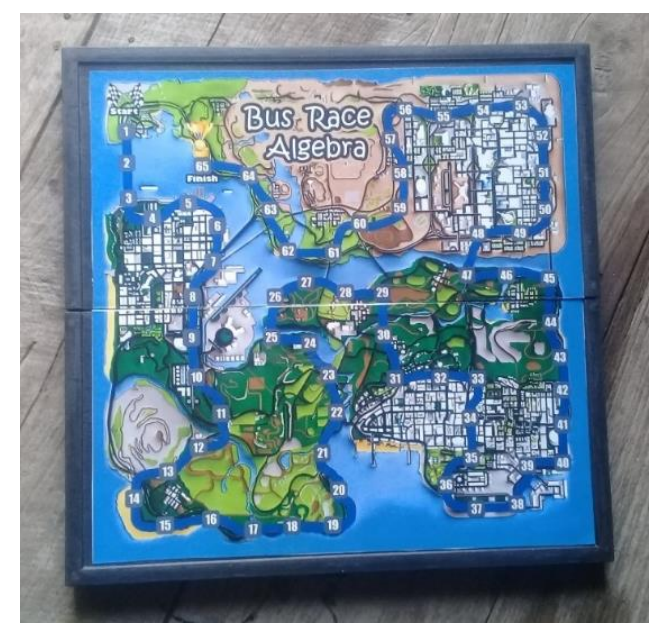

Gambar 12. Papan Permainan Bagian Luar

\section{Development (Pengembangan)}

Setelah semua desain selesai dibuat tahap selanjutnya adalah memproduksi media pembelajaran Bus Race Algebra. Pertama kali membeli bahan papan permainan yang berasal dari papan catur dan bidak permainan. Kedua, adalah mencetak kartu permainan, kemasan kartu permainan, serta buku panduan dan kunci jawaban dicetak dengan bahan kertas Ivory 400 gram. Terakhir yaitu mencetak desain papan permainan dalam bentuk stiker dengan bahan vinyl yang kemudian dilaminasi dengan plastik agar tidak mudah rusak dan anti air.

Media yang sudah selesai dibuat maka tahap selanjutnya adalah validasi media. Sebelum dilakukan validasi media, terdapat beberapa pendapat dan komentar dari validator mengenai media pembelajaran Bus Race Algebra yang akan dibuat sebagai pertimbangan bagi peneliti untuk revisi dan sebagai bukti media Bus Race Algebra sudah layak digunakan sebagai penelitian. Terdapat beberapa pendapat dari validator sebagai berikut: (a) papan permainan kurang rapi (bahan dari kayu); (b) kartu permainan ukurannya kurang besar; (c) terdapat kunci jawaban yang salah; (d) menambahkan kartu bonus yang langkahnya mundur.

Pendapat dari validator dijadikan sebagai bahan pertimbangan untuk revisi. Pendapat yang pertama digunakan sebagai saran dan revisi dengan memplitur dan juga merapikan papan permainan ke pengrajin kayu. Setelah selesai dirapikan dan diplitur ternyata kayu tetap masih melengkung sehingga papan permainan kurang simetris, sehingga bahan dari kayu tidak digunakan dan akhirnya mengganti dengan bahan plastik. Pendapat yang kedua tidak digunakan sebagai revisi dikarenakan 
jika kartu berukuran besar maka tidak dapat di kemas didalam papan permainan karena ukuran kartu permainan menyesuaikan ukuran papan permainan. Pendapat ketiga dijadikan bahan revisi karena terdapat kesalahan penulisan kunci jawaban pada nomor soal 13, yang seharusnya $47 \mathrm{~m}$ dikunci jawaban tertulis 47. Pendapat yang keempat digunakan sebagai saran dan revisi dengan menambahkan kartu bonus yang langkahnya mundur.

\section{Implementation (Implementasi)}

Tahap selanjutnya adalah mengujicobakan media Bus Race Algebra kepada siswa dibeberapa tempat di Blora dan Salatiga yang diambil secara acak sebagai responsden atau subjek penelitian. Sebelum diujikan dilapangan maka dilakukan terlebih dahulu kevalidan media dan kevalidan materi serta kepraktisan media yang di isi oleh validator dibidangnya dengan menggunakan angket. Berikut ini adalah uji yang telah dilakukan.

Uji kevalidan terbagi menjadi dua yaitu, uji kevalidan materi dan uji kevalidan media. Uji kevalidan materi maupun uji kevalidan media dilakukan oleh Danang Setyadi, M.Pd yang merupakan dosen pendidikan matematika Universitas Kristen Satya Wacana dan Indah Eka Ariyanti, S.Pd yang merupakan guru matematika di MTs PSM Randublatung dengan hasil sebagai berikut.

Tabel 4.1.

Uji Kevalidan Media

\begin{tabular}{ccc}
\hline Aspek Penilaian & $\mathbf{( \% )}$ & Kategori \\
\hline Tampilan Media & 75 & Baik \\
Pembuatan & 100 & Sangat Baik \\
Penggunaan dan Pemeliharaan & 91,7 & Sangat Baik \\
Kebermanfaatan & 77 & Baik \\
Pengemasan & 100 & Sangat Baik \\
\hline Rata-Rata & 88,34 & Sangat Baik \\
\hline
\end{tabular}

Hasil rata-rata pada Tabel 4.1 menunjukan bahwa hasil kevalidan media dengan persentase sebesar $88,34 \%$ (lebih dari $81 \%$ ) yang dikategorikan sangat baik. Dari hasil tersebut dapat disimpulkan bahwa media pembelajaran Bus Race Algebra dapat dikatakan Valid dalam segi media.

Tabel 4.2.

Uji Kevalidan Materi

\begin{tabular}{ccc}
\hline Aspek Penilaian & $\mathbf{( \% )}$ & Kategori \\
\hline Aspek Materi & 75 & Baik \\
Aspek Soal & 100 & Sangat Baik \\
Aspek konstruksi & 75 & Baik \\
\hline Rata-Rata & 83,33 & Sangat Baik \\
\hline
\end{tabular}

Hasil rata-rata pada Tabel 4.2 menunjukan bahwa hasil kevalidan media dengan persentase sebesar 83,33\% (lebih dari 81\%) yang dikategorikan sangat baik. Dari hasil tersebut dapat disimpulkan bahwa media pembelajaran Bus Race Algebra dapat dikatakan Valid dalam segi materi. Uji kepraktisan dilakukan pada saat menguji cobakan media pembelajaran Bus Race Algebra dengan cara mengisi angket yang sudah disediakan. Uji kepraktisan tersebut dilakukan oleh Danang Setyadi, M.Pd yang merupakan dosen pendidikan matematika Universitas Kristen Satya Wacana dan Indah 
Eka Ariyanti, S.Pd yang merupakan guru matematika di MTs PSM Randublatung dengan hasil sebagai berikut.

Tabel 4.3.

Uji Kepraktisan Media

\begin{tabular}{ccc}
\hline Aspek Penilaian & $(\boldsymbol{\%})$ & Kategori \\
\hline Persiapan Penggunaan & 91,7 & Baik \\
Penggunaan & 85 & Sangat Baik \\
\hline Rata-Rata & 88,35 & Sangat Baik \\
\hline
\end{tabular}

Hasil rata-rata pada Tabel 4.2 menunjukan bahwa hasil kevalidan media dengan persentase sebesar $88,35 \%$ (lebih dari $81 \%$ ) yang dikategorikan sangat baik. Dari hasil tersebut dapat disimpulkan bahwa media pembelajaran Bus Race Algebra dapat dikatakan Praktis.

\section{Evaluation (Evaluasi)}

Evaluasi merupakan tahaan yang terakhir dalam model ADDIE. Dalam penelitian ini tingkat efektifitas penggunaan media diukur dengan pencapaian hasil belajar siswa menggunakan pretest dan postest. Hasil pretest dan postest dapat dilihat pada Tabel 4.4.

\section{Tabel 4.}

\section{Hasil Pretest dan Postest}

\section{Descriptive Statistics}

\begin{tabular}{cccccc}
\hline & N & Minimum & Maximum & Mean & Std. Deviation \\
\hline Pretest & 10 & 40 & 75 & 56,00 & 10,750 \\
Postest & 10 & 75 & 100 & 84,50 & 9,846 \\
\hline Valid N (listwise) & 10 & & & & \\
\hline
\end{tabular}

Hasil pada Tabel 4.4 menunjukan peningkatan hasil belajar yang awalnya nilai rata-rata pretest 56,00 menjadi 84,50 pada nilai rata-rata postest. Nilai minimum pada pretest menunjukkan 40 dan nilai maksimumnya adalah sebesar 75. Sedangkan pada postest nilai minimal menunjukan 75 dan nilai maksimumnya adalah sebesar 100 . Kemudian dilakukan uji rerata pretest dan postest untuk menentukan ke efektifan media tersebut. Sebelum melakukan uji beda rerata maka dilakukan uji normalitas terlebih dahulu. Hasil dari uji normalitas dapat dilihat pada Tabel 4.5.

\section{Tabel 5.Hasil Uji Normalitas}

\section{Tests of Normality}

\begin{tabular}{|l|c|c|c|c|c|c|}
\hline \multirow{2}{*}{} & \multicolumn{3}{|c|}{ Kolmogorov-Smirnov $^{\mathrm{a}}$} & \multicolumn{3}{c|}{ Shapiro-Wilk } \\
\cline { 2 - 7 } & Statistic & Df & Sig. & Statistic & Df & Sig. \\
\hline Pretest &, 212 & 10 &, $200^{*}$ &, 954 & 10 &, 719 \\
Postest &, 224 & 10 &, 170 &, 884 & 10 &, 147 \\
\hline
\end{tabular}

Hasil pada Tabel 4.5 menunjukkan bahwa nilai signifikan pada kolom Kolmogorov-Smirnov dari pretest sebesar 0,719 lebih dari 0,05 dan nilai signifikan dari postest sebesar 0,147 yang lebih besar dari 0,05. Dari data tersebut menunjukkan bahwa nilai pretest dan postest dari masing-masing data sampel berasal dari populasi yang berdistribusi normal. Setelah mengetahui bahwa data tersebut 
berdistribusi normal maka tahap uji beda uji rerata dapat dilakukan. Uji parametrik yaitu menggunakan uji pair t-test dapat dilihat pada Tabel 4.6.

Tabel 6.

Hasil Uji Pair T-Test

Paired Samples Test

\begin{tabular}{|c|c|c|c|c|c|c|c|c|}
\hline & \multicolumn{5}{|c|}{ Paired Differences } & \multirow[b]{3}{*}{$\mathrm{t}$} & \multirow[b]{3}{*}{ Df } & \multirow{3}{*}{$\begin{array}{l}\text { Sig. (2- } \\
\text { tailed) }\end{array}$} \\
\hline & \multirow[b]{2}{*}{ Mean } & \multirow{2}{*}{$\begin{array}{c}\text { Std. } \\
\text { Devia } \\
\text { tion }\end{array}$} & \multirow{2}{*}{$\begin{array}{c}\text { Std. } \\
\text { Error } \\
\text { Mean } \\
\end{array}$} & \multicolumn{2}{|c|}{$\begin{array}{l}95 \% \text { Confidence } \\
\text { Interval of the } \\
\text { Difference }\end{array}$} & & & \\
\hline & & & & Lower & Upper & & & \\
\hline $\begin{array}{cc}\text { Pair } & \text { Pretest - } \\
1 & \text { Postest }\end{array}$ & $-29,500$ & 6,852 & 2,167 & $-34,401$ & $-24,599$ & $-13,615$ & 9 &, 000 \\
\hline
\end{tabular}

Hasil pada Tabel 6 menunjukan bahwa nilai signifikan pada kolom Sig.(2-tailed) adalah sebesar 0,000 kurang dari 0,05 sehingga data tersebut terdapat beda yang signifikan. Berdasarkan hasil nilai dari rata rata pretest dan postest menunjukan terdapat peningkatan hasil belaja siswa. Sehingga media pembelajaran Bus Race Algebra dapat dikatakan Efektif.

\section{KESIMPULAN}

Berdasarkan hasil penelitian yang sudah selesai dilakukan melalui hasil dan pembahasan sehingga didapatkan kesimpulan sebagai berikut: 1) media pembelajaran Bus Race Algebra dinyatakan valid digunakan dari segi materi maupun media berdasarkan hasil angket yang diberikan kepada ahli media dan ahli materi. Hasil butir angket dari ahli media dan ahli materi menunjukan presentase rata-rata nilai kevalidan dari segi materi adalah $88,34 \%$ dan kevalidan dari segi media adalah $83,33 \%$ dengan kategori sangat baik sehingga media ini valid diujicobakan di lapangan; 2) media ini juga praktis digunakan dalam proses pembelajaran karena bentuknya yang kecil dan mudah dibawa dibuktikan dengan hasil angket yang diberikan kepada ahli media menunjukan presentase rata-rata nilai kepraktisan sebesar $88,35 \%$ dengan kategori sangat baik sehingga media ini dapat praktis untuk digunakan dalam proses belajar mengajar 3) hasil nilai dari uji pair t-test adalah kurang dari 0,05 yang menunjukkan terdapat perbedaan dari hasil nilai siswa yaitu dengan rata rata nilai pretest 56,00 meningkat menjadi 84,50 pada nilai postest, maka media ini efektif digunakan untuk meningkatkan hasil belajar siswa dalam materi bentuk aljabar. Lembar pendapat siswa mendapatkan respon yang sangat positif terhadap media pembelajaran ini. Rata-rata presentase pendapat siswa terhadap media Bus Race Algebra adalah 90,00\% dengan kategori sangat baik yang ditinjau dari pemberian angket respon siswa terhadap media, sehingga media tersebut layak digunakan sebagai alat peraga dalam materi bentuk aljabar untuk kelas VII SMP.

Berdasarkan hasil penelitian, maka disarankan media pembelajaran Bus Race Algebra digunakan untuk guru dan siswa dalam kegiatan belajar mengajar pada materi bentuk aljabar, serta disarankan mengembangkan media pembelajaran Bus Race Algebra ini dalam bentuk digital untuk 
PEngembangan Media Bus Race Algebra Pada Materi Bentuk Aljabar Untuk Siswa Kelas VII SMP, Eko Yulianto Prambudi, Tri Nova Hasti Yunianta

penelitian-penelitian selanjutnya dikarenakan perkembangan jaman di era digital ini dapat mempengaruhi minat siswa untuk belajar

\section{Daftar Pustaka}

Afandi, Rifki. (2015). Pengembangan Media Pembelajaran Permainan Ular Tangga Untuk Meningkatkan Motivasi Belajar Siswa Dan Hasil Belajar Di Sekolah Dasar. Jurnal Inovasi Pembelajaran, 1 (1), 77-89.

Arsyad, Azhar. (2011). Media Pembelajaran. Jakarta: PT. Raja Grafindo Persada.

Aziz, Lalu Abdul. (2018). Pengembangan Media Pembelajaran Permainan Ular Tangga Materi Operasi Hitung Pecahan Kelas V Sekolah Dasar Negeri 24 Cakranegara Tahun Pelajaran 2017/2018. Jurnal Media Pembelajaran Matematika, 6 (1), 318-323

Harsantik, S. (2014). Pengembangan MediaGame Tebak Gambar Untuk Membantu Eksplorasi Karir Siswa Kelas VII SMP Negeri 1 Panggul. Jurnal Unnesa, 4 (3), 1-9.

Harsono, D.N., Prihatnani, E., (2018). Pengembangan Permainan Domat Card Pada Materi Sistem Persamaan Linier Satu Variabel. MAJU 5, 1-13.

Indrawati, D., Suardiman, S.P., Uny, Pp., (2013). Pengembangan Media Travel Game untuk Pembelajaran Perkalian dan Pembagian Bilangan Pecahan Matematika SD Kelas V. J. Prima Edukasia 1, 12.

Indriana, Dina. (2011). Ragam Alat Bantu Media Pengajaran. Yogyakarta: Diva Press

Kharimah, R.F., Suporwoko, Wahyuningsing, D. (2014). Pengembangan Media Pembelajaran Ular Tangga Fisika Untuk Siswa SMP/Mts Kelas VII. Jurnal Pendidikan Fisika. 1 (2), 6-11

Latief, M., (2017). Pengembangan Permainan Ular Jarpa Sebagai Media Pembelajaran Pada Materi Pokok Asam-Basa. Jurna Penelit. Pendidik. Insani 20, 101-107.

Listiani, D., Prihatnani E. (2018). pengembangan media pembelajaran dart board math bagi siswa kelas vii smp. Jurnal math didactic, 4(1), 21 - 33

Malalina. (2017). Media Ular Tangga Segitiga Pada Materi Luas dan Keliling Segitiga. Journal Cendekia, 1(2), 35-40.

Mujito, Imam Sunarno. (2018). Pengembangan Board Game Media Edukasi Tastarok Sebagai Media Permainan Simulasi. Journal of Borneo Holistic Health, 1 (2),180-189.

stem Pembelajaran. Jakarta: Dian Rakyat.

Putri, A.W., Yunianta, T.N.H. (2018). Pengembangan Media Pembelajaran Board Game "The Labyrinth of Trigonometry" Pada Materi Trigonometri Kelas X SMA. Satya Widya, 2 (34), 88-100

Sadiman, A.S., Rahardjo, R., Haryono, A., dan Rahardjito. (2010). Media Pendidikan (Pengertian, Pengembangan, Dan Pemanfaatannya). Jakarta: Rajawali Pers.

Setyaningsih, M.D., Dewi, N.R., (2015). Pengembangan Media Papan Permainan Berbasis Scince Edutainment Tema Makanan Untuk Siswa Kelas VIII. USEJ 4, 965-972.

Sugiyono. (2012). Metode Penelitian Kuantitatif Kualitatif dan R\&D. Bandung: Alfabeta 
Warsitasari, Wahyu Dwi. (2015). Berpikir Aljabar Dalam Pemecahan Masalah Matematika. APOTEMA, 1(1), 1-17 